\title{
Lactococcin 972, a bacteriocin that inhibits septum formation in lactococci
}

\author{
Beatriz Martínez, ${ }^{1}$ Ana Rodríguez ${ }^{1}$ and Juan E. Suárez ${ }^{1,2}$ \\ Author for correspondence: Juan E. Suárez. Tel: +34 9851035 59. Fax: +34 985103148. \\ e-mail: jsuarez@sauron.quimica.uniovi.es
}

\begin{abstract}
1 Instituto de Productos Lácteos de Asturias (IPLACSIC), 33300-Villaviciosa, Asturias, Spain

2 Departamento de Biología Funcional, Area de Microbiología, Universidad de Oviedo, 33006-Oviedo, Asturias, Spain
\end{abstract}

\begin{abstract}
Addition of lactococcin 972 to exponentially growing sensitive cultures of Lactococcus lactis resulted in cell elongation and widening. Thin sections revealed that septum invagination was blocked. Cell growth progressed until most cells showed equatorial constriction and even initial deposition of material at the septum ring, although cell division did not proceed any further. The increase in the incorporation of labelled precursors into the cell wall shifted from an exponential to a linear mode in treated cultures, subsequently being arrested. Gross degeneration of the cells was observed prior to cell death, followed by slow lysis of the culture. In contrast, stationary-phase cultures remained unaffected.
\end{abstract}

Keywords: lactococcin 972, septum biosynthesis, bacteriocin, Lactococcus lactis

\section{INTRODUCTION}

Lactic acid bacteria produce a wide variety of proteinaceous antimicrobial agents named bacteriocins. These have been grouped into three clusters according to their characteristics: class I (lantibiotics), class II (small heat-stable polypeptides composed of unmodified biological amino acids), and class III (large heat-labile proteins) (Nes et al., 1996). However, this classification probably needs to be widened to include other peptides that cannot be properly placed in any of the above groups, such as the enterocins L50, which are devoid of leader peptides (Cintas et al., 1998), and lactococcin 972, as will be shown below.

The potential application of bacteriocins of lactic acid bacteria as food preservatives requires an in-depth knowledge of how they exert their bactericidal effect. Most bacteriocins whose primary mode of action is known act at the plasma membrane. It has been proposed that these peptides form poration complexes that traverse the phospholipid bilayer. This provokes membrane permeabilization and hence depletion of the proton-motive force of sensitive cells (Ojcius \& Young, 1991; Driessen et al., 1995; Abee, 1995).

In some cases, the pore only allows leakage of ions, mainly $\mathrm{K}^{+}$and, in the cases in which this has been tested, inorganic phosphate (Parente et al., 1996; McAuliffe et al., 1998; Barrena-González et al., 1996; Moll et al., 1998). The depletion of phosphate presumably causes a shift in the ADP/ATP intracellular equilibrium leading to ATP hydrolysis and cell de-energization (Abee et al., 1994). In other cases, the size of the pores may increase, thus allowing the subsequent release of larger molecules such as amino acids and even ATP (González et al., 1996; Zajdel et al., 1985; Maisnier-Patin et al., 1996).

In contrast, the type $B$ lantibiotics mersacidin and actagardine, which are globular peptides with no amphipathic properties, kill susceptible cells by interfering with cell wall biosynthesis, namely at the level of transglycosylation, the reaction that mediates integration of new monomers into pre-existing peptidoglycan (Brötz et al., 1998).

The plasma membrane was found not to be the primary target of lactococcin 972. Sensitive cells treated with the bacteriocin did not suffer either leakage of cytoplasmic solutes or significant inhibition of macromolecular synthesis, which would be immediately observed upon loss of the proton-motive force (Martínez et al., 1996; González et al., 1996). Furthermore, lactococcin 972 is not a hydrophobic peptide, a typical feature of poreforming bacteriocins, as was deduced from its amino acid sequence (Martínez et al., 1999). This bacteriocin is also unusual because its functional form is a homodimer whose components are weakly bound; they can be separated by heating to $50^{\circ} \mathrm{C}$ or by acidic $\mathrm{pH}$, the resulting monomers being devoid of any antibacterial activity (Martínez et al., 1996).

In this report, we present data indicating that the primary target of lactococcin 972 is the inhibition of septum formation in susceptible lactococci. This results in deformation of the cells as visualized by optical microscopy, and subsequently in gross structural changes that lead to cell death. 

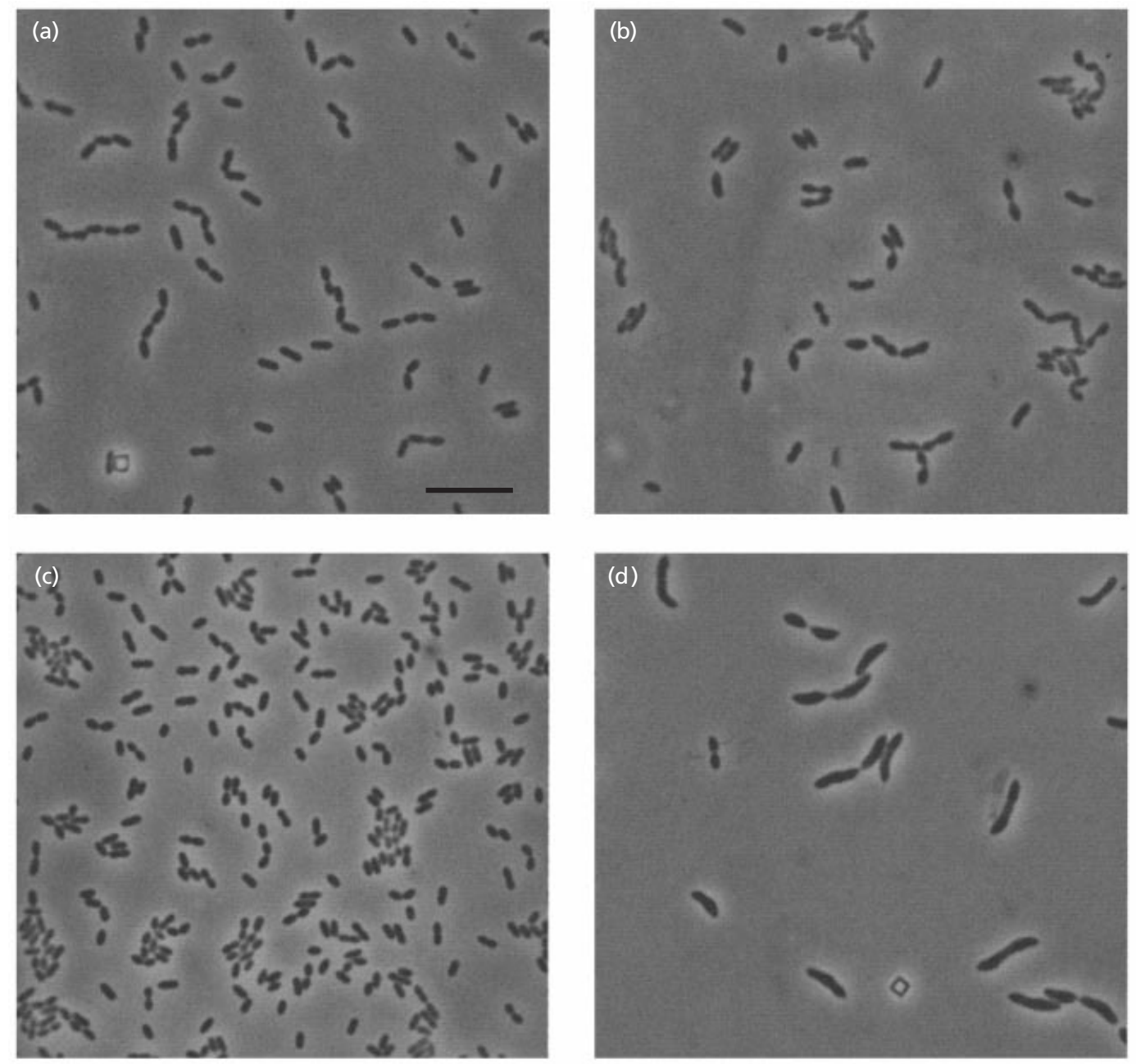

Fig. 1. Effect of lactococcin 972 on L. lactis MG1614 morphology as seen by optical microscopy. The bacteriocin was added to exponentially growing cultures and the photographs were taken at 30 (b) and 90 (d) min after lactococcin 972 addition. (a) and (c) are samples from control cultures taken at the same time as (b) and (d), respectively. Bar, $10 \mu \mathrm{m}$.

\section{METHODS}

Bacterial strains and culture conditions. Lactococcus lactis subsp. lactis IPLA 972 and L. lactis MG1614 (Strr Rif $\left.{ }^{r}\right)$ were used as the lactococcin 972 producer (Martínez et al., 1996) and sensitive strain, respectively. Cultures were grown in M17 broth (Biokar) supplemented with $0.5 \%$ lactose (LM17) for $L$. lactis IPLA 972 or 0.5\% glucose (GM17) for L. lactis MG1614. The strains were incubated at $32{ }^{\circ} \mathrm{C}$. The stock cultures were maintained at $-80{ }^{\circ} \mathrm{C}$ in broth containing $10 \%(\mathrm{v} / \mathrm{v})$ glycerol and propagated twice before each experiment.

Bacteriocin purification and quantification. Lactococcin 972 was extracted from supernatants of late-exponential-phase cultures of L. lactis IPLA 972 as previously described (Martínez et al., 1996). The protein concentration was determined with the Bio-Rad Protein Assay kit. The bacteriocin activity was quantified by the agar diffusion test (Reddish, 1929). Twofold serial dilutions were tested and the highest one that produced a clear zone of growth inhibition on the indicator lawn was defined as 1 arbitrary unit of activity $\mathrm{ml}^{-1}\left(\mathrm{AU} \mathrm{m} \mathrm{m}^{-1}\right.$ ), which corresponds to a lactococcin 972 concentration of $12 \cdot 7 \mathrm{nM}$.

Cell wall biosynthesis measurements. Synthesis of peptido- glycan in exponentially growing cultures of L. lactis MG1614 $\left(\mathrm{OD}_{600} 0 \cdot 2\right)$ was followed by measuring the continuous incorporation of $\mathrm{N}$-acetyl-D-[1- $\left.{ }^{3} \mathrm{H}\right]$ glucosamine $(192 \mathrm{GBq}$ $\mathrm{mmol}^{-1}, 37 \mathrm{MBq} \mathrm{m} l^{-1}$ ), at a final concentration of $37 \mathrm{kBq}$ $\mathrm{ml}^{-1}$, into trichloracetic-acid-insoluble material. Half of the cultures were treated with purified lactococcin 972 (50 AU $\mathrm{ml}^{-1}$ ), which was replaced in the controls with the same

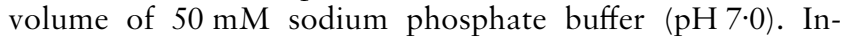
cubation was at $32{ }^{\circ} \mathrm{C}$ and proceeded for $180 \mathrm{~min}$. Samples were collected at intervals and processed as described previously (Rodríguez et al., 1986).

Optical and electron microscopy. Samples were taken from exponentially growing cultures of L. lactis MG1614 before and after (up to $120 \mathrm{~min}$ ) addition of lactococcin 972 (50 AU $\mathrm{ml}^{-1}$ ). Light micrographs were taken with an Olympus BH-2 phase-contrast microscope. For negatively stained and thinsection electron microscopy, cells were harvested by centrifugation and washed twice in sterile distilled water. Cell suspensions were negatively stained with aqueous $1 \%$ uranyl acetate $(\mathrm{pH} 4 \cdot 0)$. For thin-section preparation, washed cells were embedded in $2 \%$ Noble agar (Difco), fixed overnight in $1 \%$ osmium tetraoxide in sodium diethylbarbiturate/acetate 
buffer (pH 6.0) (Ryter \& Kellenberger, 1958), and stained with $2 \%$ uranyl acetate in the same buffer for $2 \mathrm{~h}$. Dehydration was done in a graded acetone series $(25-100 \%)$, and embedding in Epon 812. Sections were stained with $2 \%$ uranyl acetate in ethanol and Reynolds' lead citrate (Reynolds, 1963). Negatively stained samples and thin sections were observed with a JEOL 2000 EX-II electron microscope operating at $80 \mathrm{kV}$.

Flow cytometry analysis. Early-exponential-phase cultures $\left(\mathrm{OD}_{600} 0 \cdot 2\right)$ of $L$. lactis MG1614 were divided into aliquots of $5 \mathrm{ml}$. Purified lactococcin $972\left(50 \mathrm{AU} \mathrm{ml}^{-1}\right)$ or the same volume of $50 \mathrm{mM}$ sodium phosphate buffer $(\mathrm{pH} 7 \cdot 0)$ were added to the test and control samples, respectively. Culture aliquots $(0.5 \mathrm{ml})$ were collected at intervals, centrifuged, washed twice with phosphate-buffered saline (pH 7.0) (PBS) and resuspended in $0.5 \mathrm{ml}$ PBS containing $5 \mu \mathrm{g} \mathrm{ml}^{-1}$ propidium iodide (Sigma). Samples were allowed to stain for $5 \mathrm{~min}$ at room temperature before being analysed by flow cytometry. The stock solution was prepared by dissolving the propidium iodide to a final concentration of $1 \mathrm{mg} \mathrm{ml}^{-1}$ in ethanol, immediately prior to use. The flow cytometer used was a Bryte-HS (Bio-Rad) equipped with WinBryte software (Bio$\mathrm{Rad})$. Ilumination was provided by a $75 \mathrm{~W}$ lamp.

\section{RESULTS}

\section{Structural changes of $L$. lactis cells induced by lactococcin 972}

It has previously been shown that addition of lactococcin 972 to exponential cultures of lactococci resulted in a sharp reduction in viable counts. However, the cells remained metabolically active: they synthesized DNA, RNA and proteins at an almost normal rate for $90 \mathrm{~min}$ (Martínez et al., 1996). This means that cell death was a late event, possibly secondary to other, more subtle, earlier effects. In spite of this, washing the bacteriocin as early as $10 \mathrm{~min}$ after its addition to the cultures did not reverse its bactericidal effect, indicating either that the peptide had become irreversibly bound to its target or that the cells had become programmed to die. While looking for early effects of lactococcin 972, it was noticed that exponential-phase L. lactis MG1614 cells lost their spherical shape and became elongated (Fig. 1). This was followed by slow lysis of the culture, which started $2 \mathrm{~h}$ after addition of the bacteriocin. In contrast, stationary-phase cells were much more refractory to lactococcin 972 action (data not shown).

These data suggested a potential effect of the bacteriocin on cell wall biosynthesis. To test this hypothesis, we studied the incorporation of the peptidoglycan precursor $\mathrm{N}$-acetylglucosamine into trichloroacetic-acid-insoluble material in both treated and untreated cultures (Fig. 2). Whereas the control cultures showed an exponential increase in incorporation of the precursor, treated samples showed a linear increase, possibly indicating that synthesis of peptidoglycan proceeded at a constant rate, i.e. no new initiation sites were created in the presence of the bacteriocin. After $2 \mathrm{~h}$ incubation, a clear inhibitory effect became evident in the treated cultures (Fig. 2).

To confirm the effect of lactococcin 972 on cell wall metabolism, treated cells were examined by electron microscopy. Negative staining revealed a gross change

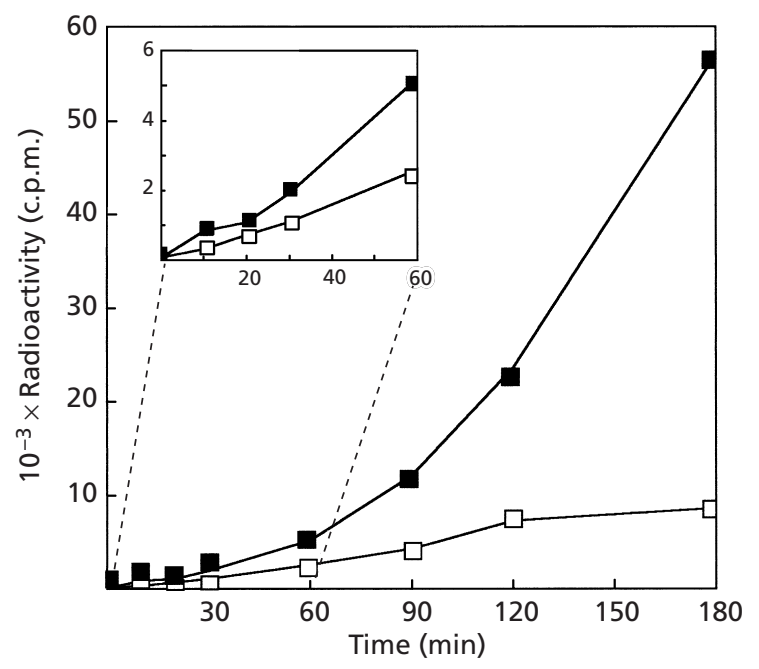

Fig. 2. Biosynthesis of peptidoglycan by cultures of $L$. lactis treated $(\square)$ or untreated ( $\square$ ) with lactococcin 972 as measured by incorporation of $\mathrm{N}$-acetyl-D-[1- $\left.{ }^{3} \mathrm{H}\right]$ glucosamine into trichloroacetic-acid-insoluble material. Samples were taken in triplicate.

in cell shape. In the control cultures, the typical spherical cells were observed (Fig. 3a). These occurred in short chains of four to six individuals and showing growth rings in their equatorial zones. In the treated cultures, elongated, irregular bacillary forms were detected. These showed transverse electron-dense lines that possibly corresponded to the growth rings. These rings were located at zones of cell widening, which are likely to be the equatorial zones of the cocci (Fig. 3b). This was an initial indication that the action of lactococcin 972 was not the inhibition of cell growth but rather cell division. This second hypothesis was tested by the analysis of thin sections of exponentially growing cultures. Untreated cells showed the typical structure of Gram-positive cocci, with a thick, uniform, smooth wall, a membrane attached to the wall and a granular cytoplasm. In the cytoplasm a clear, fibrillar mass of metabolically active DNA was visible, as were the division septa which, while growing, were usually associated with mesosomes (Fig. 3c, d). Most of the cells were dividing, as expected in an early-exponential-phase culture. Following the addition of the bacteriocin, increasing numbers of cells appeared to be blocked at the beginning of the division process, i.e. they had elongated shapes with the typical shallow constriction at their equatorial zones which, in addition, showed septum primordia (Fig. 3e, f). However, these septa did not progress further, as none of the cells observed from subsequent samples showed a completed cross-wall. After $90 \mathrm{~min}$ incubation, more drastic changes were observed: the cells became elliptical, the DNA bundle was indistinguishable, intracytoplasmic vesicles appeared and both the smooth external and internal surfaces of the cell wall became wrinkled (Fig. 3g, h). Finally, cell lysis was detected in cultures incubated over $2 \mathrm{~h}$ in the presence of lactococcin 972 (data not shown). 
(a)
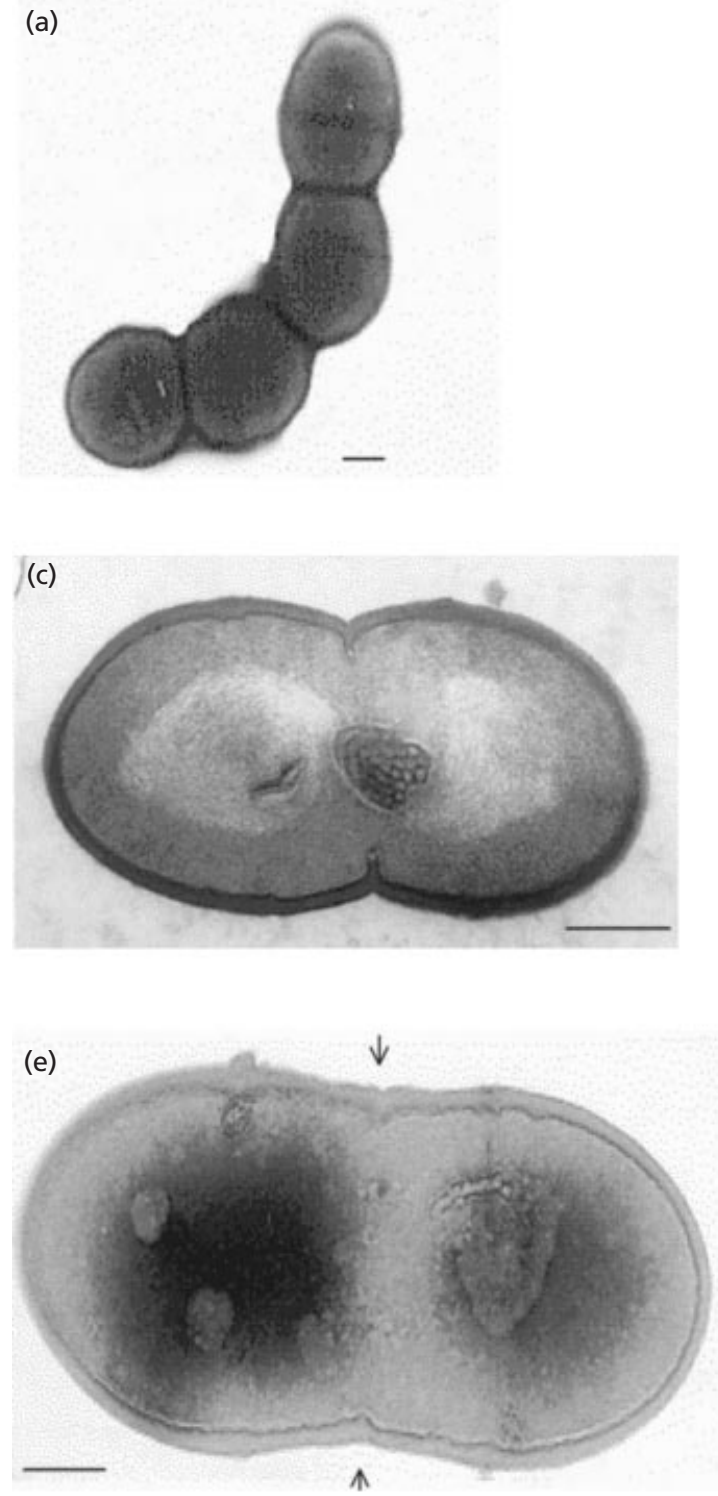

(g)

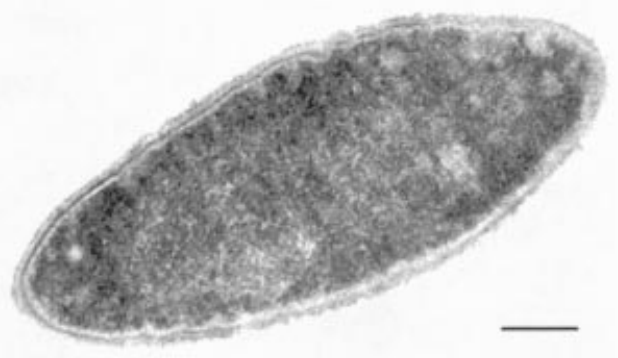

(b)
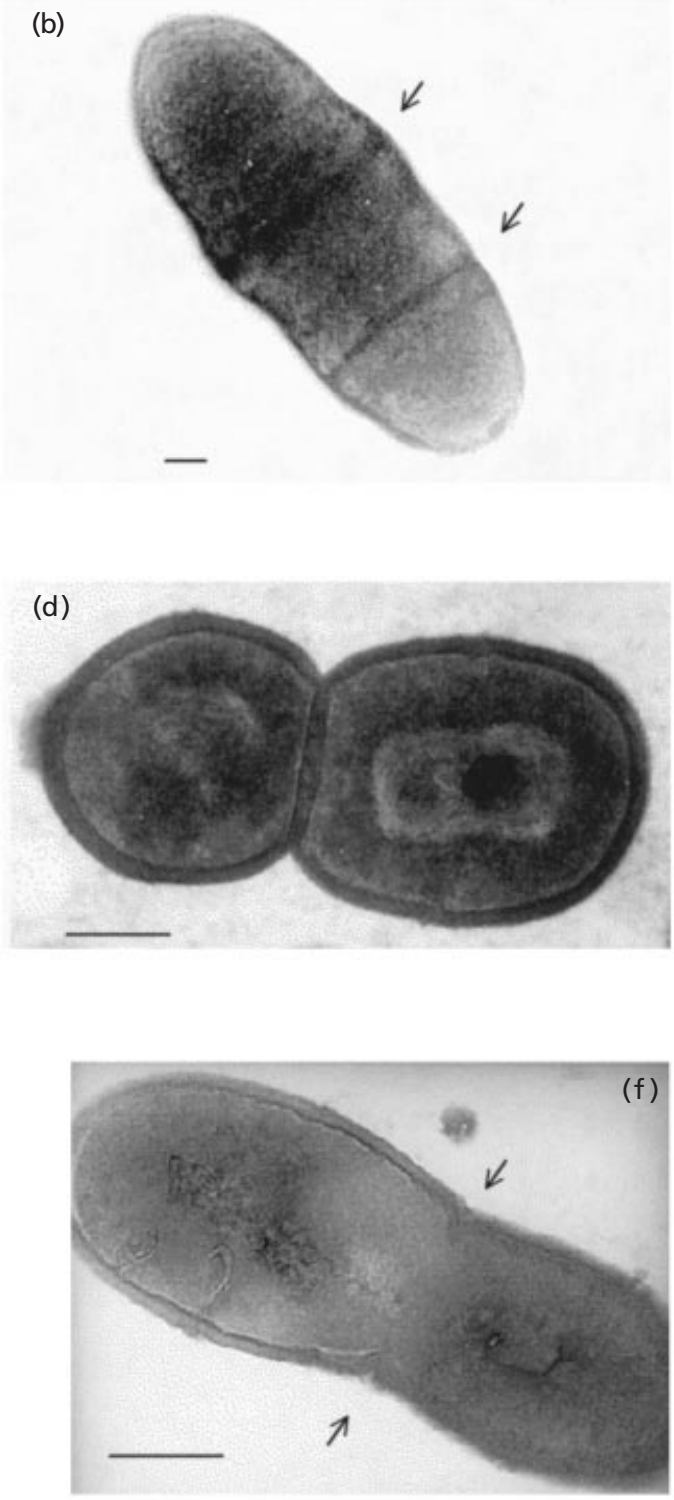

(f)

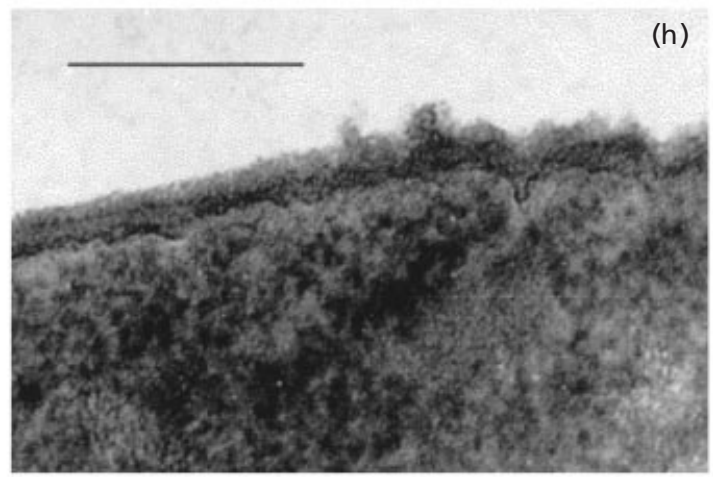

Fig. 3. Effect of lactococcin 972 on the morphology of exponentially growing cells of L. lactis MG1614 as seen by electron microscopy. (a, b) Negatively stained cells from untreated and treated cultures respectively. The arrows in (b) indicate the growth rings. (c-h) Thin sections of controls $(c, d)$ and cultures treated with the bacteriocin for $30(e, f)$ and $90(g, h)$ min. The arrows in (e) and (f) point to the septum primordia. A detail of the change in cell wall architecture is shown in (h). Bars, $100 \mathrm{~nm}$. 


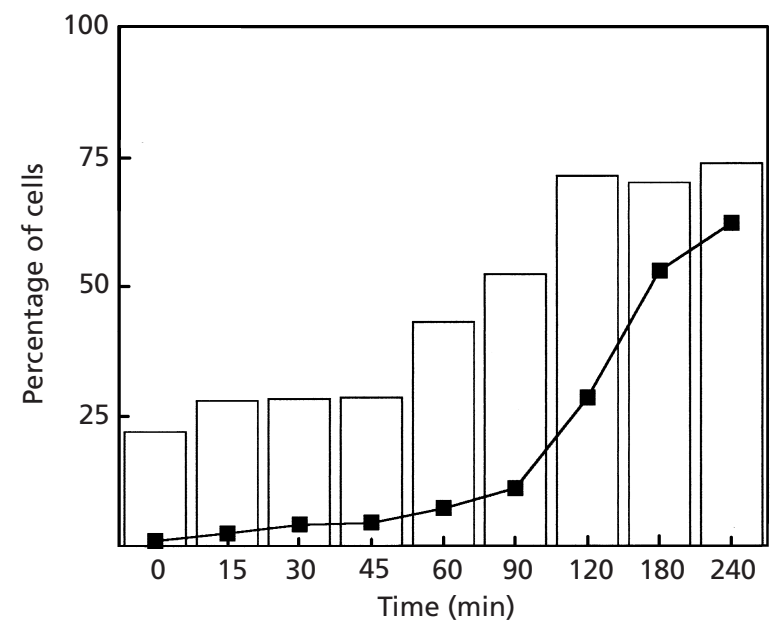

Fig. 4. Effect of lactococcin 972 on the morphology and viability of L. lactis MG1614 as recorded by flow cytometry. The bacteriocin was added to exponential cultures at time 0 . The vertical bars indicate the proportion of cells with aberrant shapes. Since the control cultures presented a variety of forms we had to compromise by taking a $20 \%$ variation as normal so as to optimize the ability of the flow cytometer to detect the changes observed in treated cultures. The curve indicates the proportion of killed cells as recorded by permeability to propidium iodide.

\section{Kinetics of cell deformation and death induced by lactococcin 972}

To get a deeper insight into the correlation between cell deformation and the loss of viability, a flow-cytometry experiment was performed in which the changing shape of the cells and their permeability to propidium iodide were recorded (Fig 4). Propidium iodide fluoresces upon intercalation in the double helix of DNA but cannot pass through the plasma membrane. Consequently, it may be used to show any loss in membrane integrity, and thus as an indicator of cell viability. No extreme changes in shape were measured by this method until $60 \mathrm{~min}$ after addition of lactococcin 972 to the culture (although these changes were observed much earlier by phase-contrast microscopy; see Fig. 1). From this time point onwards, deformation of the cells preceded the loss of cell viability. In the control cultures, the percentage of deformed cells did not increase throughout the experiment and no fluorescence was recorded (data not shown).

\section{DISCUSSION}

The reported data seem to indicate that an early target of lactococcin 972 action is septum biosynthesis. This effect is probably not lethal by itself. Treated cells continue synthesizing macromolecules and growing until a new round of division starts. At this point, the cell cycle seems to freeze and cell division does not progress any further. This apparently triggers secondary effects such as cell widening, loss of membrane integrity and lysis, which become evident after 60 min incubation.
This proposed mode of action is consistent with the fact that lactococcin 972 hardly affects stationary-phase cells. Presumably, they do not have a target because no division occurs at that stage.

Septum formation is a complex process, best studied in Escherichia coli, in which the products of at least nine genes are involved (Lutkenhaus \& Addinall, 1997). The process occurs in two stages. In the initial stage, a distant homologue of eukaryotic tubulin, FtsZ, forms the so-called cytokinetic ring, which is believed to be responsible for the constriction that the cell suffers at the septum region (Erickson et al., 1996; Mukherjee \& Lutkenhaus, 1994). In the second stage, which is sensitive to $\beta$-lactam antibiotics, the transpeptidase PBP3, which is the product of gene $\mathrm{ftsI}$, mediates formation of the cross-links between the peptidoglycan strands at the growing septum (Wang et al., 1998; Botta \& Park, 1981). Cells devoid of FtsZ or PBP3 form smooth and blunt constricted multinucleate filaments, respectively, indicating that FtsZ is needed to initiate constriction while PBP3 is important for septum invagination (Pogliano et al., 1997). If $L$. lactis has a septum formation machinery similar to that of $E$. coli, we must conclude that lactococcin 972 does not affect the initial stage of the process, since cells treated with the bacteriocin show equatorial constriction and even septum primordia. It presumably rather inhibits one or more steps at the second stage, i.e. septum invagination. We might speculate that lactococcin 972 affects PBP3 function. However, this protein, at least in E. coli, interacts with many others, such as FtsA, FtsQ and FtsW (Wang et al., 1998; Tormo et al., 1986). Thus, any of these might be the target of the bacteriocin. In fact, some differences are observed with respect to E. coli ftsI mutants. For example, treated L. lactis cells do not form long filaments, although they suffer an elongation that precedes macromolecular synthesis arrest and death of the cell.

This might be due to the different patterns of cell wall growth shown by rod-shaped bacteria and cocci. In the first case, exemplified by E. coli and Bacillus subtilis, longitudinal growth is effected by deposition of new wall monomers all along the rod. In contrast, septum formation is a localized process in which an annular disk of wall material is produced inwards to bisect the two daughter cells (de Chastelier et al., 1975; Archibald et al., 1993). Therefore, inhibition of septum formation may not necessarily impair elongation of the cells, which would result in the formation of filaments. In cocci, both elongation and septum formation take place at an annular band located in the equatorial zone of the cell (Cole \& Hahn, 1962). This band splits during growth and the resulting bands move away as new material is placed between them. The septum is initiated at this single starting point and proceeds via centripetal growth (Daneo-Moore \& Shockman, 1977; Archibald et al., 1993). In other words, cell elongation and septum formation are physically and, possibly, functionally linked in Gram-positive cocci. It is thus conceivable that inhibition of septum formation would affect cell growth 
as well. This might trigger deformation and lysis of the cells, especially if the autolysins that promote wall turnover and cell separation (Wong et al., 1974; Koch \& Doyle, 1986) are not inhibited.

Most of the data on lactococcin 972 indicate that it is an unusual bacteriocin. In contrast to virtually all antimicrobial peptides from Gram-positive bacteria, its active form is a homodimer, and it is sensitive to heat and low pH (Martínez et al., 1996). Furthermore, it is probably exported via a Sec-dependent mechanism (Martínez et al., 1999) and acts on cell wall biosynthesis, not, as do most bacteriocins, by opening pores in the plasma membrane. Recently, a new bacteriocin, enterolysin A, which is homologous to different cell-wall-lytic proteins, has been described (Nilsen et al., 1999). Although its mode of action has not yet been studied, the cell wall might be its target. It might hence be reasonable to consider the creation of a new subgroup of bacteriocins among those already described in class II of Nes et al. (1996), to include bacterocins whose target is the cell wall. Further studies on the primary target of lactococcin 972 are in progress in order to assign it definitely to the subgroup suggested above.

\section{ACKNOWLEDGEMENTS}

We thank Alberto Alvarez, Facultad de Farmacia, Universidad Complutense de Madrid, for performing the flow cytometry analysis, and Víctor Ladero for helping us with the art work. This work was financially supported by grants ALI93-0873C02 and ALI97-0658-C03 from the Comisión Interministerial de Ciencia y Tecnología of Spain. B. M. was the recipient of a predoctoral fellowship from the Ministerio de Educación y Ciencia of Spain.

\section{REFERENCES}

Abee, T. (1995). Pore-forming bacteriocins of Gram-positive bacteria and self-protection mechanisms of producer organisms. FEMS Microbiol Lett 129, 1-10.

Abee, T., Klaenhammer, T. R. \& Letellier, L. (1994). Kinetics studies of the action of lacticin $\mathrm{F}$, a bacteriocin produced by Lactobacillus johnsonii that forms poration complexes in the cytoplasmic membrane. Appl Environ Microbiol 60, 1006-1013.

Archibald, A. R., Hancock, I. C. \& Harwood, C. R. (1993). Cell wall structure, synthesis and turnover. In Bacillus subtilis and other Gram positive bacteria, pp. 381-410. Edited by A. L. Sonenshein and others. Washington DC: American Society for Microbiology.

Barrena-González, C., Huot, E. \& Petitdemange, H. (1996). Mode of action of a bacteriocin (J46) produced by Lactococcus lactis subsp. cremoris J46. J Food Prot 59, 955-962.

Botta, G. A. \& Park, J. T. (1981). Evidence for involvement of penicillin-binding protein 3 in murein synthesis during septation but not during cell elongation. J Bacteriol 145, 333-340.

Brötz, H., Bierbaum, G., Reynolds, P. E. \& Sahl, H. G. (1998). The lantibiotic mersacidin inhibits peptidoglycan synthesis by targeting lipid II. Antimicrob Agents Chemother 42, 154-160.

de Chastelier, C., Hellio, R. \& Ryter, A. (1975). Study of cell wall growth in Bacillus megaterium by high resolution autoradiography. J Bacteriol 123, 1184-1196.

Cintas, L. M., Casaus, P., Holo, H., Hernández, P. E., Nes, I. F. \& Havarstein, L. S. (1998). Enterocins L50A and L50B, two novel bacteriocins from Enterococcus faecium L50, are related to staphylococcal hemolysins. J Bacteriol 180, 1988-1994.

Cole, R. M. \& Hahn, H. H. (1962). Cell wall replication in Streptococcus pyogenes: immunofluorescent methods applied during growth show that new wall is formed equatorially. Science 135, 722-724.

Daneo-Moore, L. \& Shockman, G. D. (1977). The bacterial cell surface in growth and division. In The Synthesis, Assembly and Turnover of Cell Surface Components, pp. 597-715. Edited by G. Poste \& G. L. Nicholson. Amsterdam: Elsevier.

Driessen, A. J., van der Hooven, H. W., Kuiper, W., van de Kamp, M., Sahl, H. G., Konings, R. N. \& Konings, W. N. (1995). Mechanistic studies of lantibiotic induced permeabilization of phospholipid vesicles. Biochemistry 34, 1606-1614.

Erickson, H. P., Taylor, D. W., Taylor, K. A. \& Bramhill, D. (1996). Bacterial cell division protein FtsZ assembles into protofilament sheets and minirings, structural homologs of tubulin polymers. Proc Natl Acad Sci USA 93, 519-523.

González, B., Glaasker, E., Kunji, E. R. S., Driessen, A. J. M., Suárez, J. E. \& Konings, W. N. (1996). Bactericidal mode of action of plantaricin C. Appl Environ Microbiol 62, 2701-2709.

Koch, A. L. \& Doyle, R. J. (1986). Growth strategy for the Gram positive rod. FEMS Microbiol Rev 32, 247-254.

Lutkenhaus, J. \& Addinall, S. G. (1997). Bacterial cell division and the $\mathrm{Z}$ ring. Annu Rev Biochem 66, 93-116.

McAuliffe, O., Ryan, M. P., Ross, R. P., Hill, C., Breeuwer, P. \& Abee, T. (1998). Lacticin 3147, a broad-spectrum bacteriocin which selectively dissipates the membrane potential. Appl Environ Microbiol 64, 439-445.

Maisnier-Patin, S., Forni, E. \& Richard, J. (1996). Purification, partial characterisation and mode of action of enterococcin EFS2, an antilisterial bacteriocin produced by a strain of Enterococcus faecalis isolated from a cheese. Int J Food Microbiol 30, 255-270.

Martínez, B., Suárez, J. E. \& Rodríguez, A. (1996). Lactococcin 972, a homodimeric lactococcal bacteriocin whose primary target is not the plasma membrane. Microbiology 142, 2393-2398.

Martínez, B., Fernández, M., Rodríguez, A. \& Suárez, J. E. (1999). Synthesis of lactococcin 972, a bacteriocin produced by Lactococcus lactis IPLA 972, depends on the expression of a plasmidencoded bicistronic operon. Microbiology 145, 3155-3161

Moll, G., Hildeng-Hauge, H., Nissen-Meyer, J., Nes, I. F., Konings, W. N. \& Driessen, A. J. (1998). Mechanistic properties of the twocomponent bacteriocin lactococcin G. J Bacteriol 180, 96-99.

Mukherjee, A. \& Lutkenhaus, J. (1994). Guanine nucleotidedependent assembly of FtsZ into filaments. J Bacteriol 176, 2754-2758.

Nes, I. F., Diep, B. D., Havarstein, L. S., Brurberg, M. B., Eisink, V. \& Holo, H. (1996). Biosynthesis of bacteriocins in lactic acid bacteria. Antonie Leeuwenhoek 70, 113-128.

Nilsen, T., Nes, I. F. \& Holo, H. (1999). Enterolysin A, a bacteriolytic protein produced by Enterococcus faecalis LMG 2333. VI Symposium on Lactic Acid Bacteria. Veldhoven, the Netherlands, abstract C61.

Ojcius, D. M. \& Young, J. D. (1991). Cytolytic pore forming proteins and peptides, is there a common structural motif? Trends Biochem Sci 16, 225-229.

Parente, E., Moles, M. \& Ricciardi, A. (1996). Leucocin F10, a bacteriocin from Leuconostoc carnosum. Int J Food Microbiol 33, 231-243.

Pogliano, J., Pogliano, K., Weiss, D. S., Losick, R. \& Beckwith, J. (1997). Inactivation of FtsI inhibits constriction of the FtsZ 
cytokinetic ring and delays the assembly of FtsZ rings at potential division sites. Proc Natl Acad Sci USA 94, 559-564.

Reddish, G. F. (1929). Methods for testing antiseptics. J Lab Clin Med 14, 649-658.

Reynolds, E. S. (1963). The use of lead citrate at high $\mathrm{pH}$ as electron opaque stain in electron microscopy. J Cell Biol 17, 209-212.

Rodríguez, A., Caso, J. L., Hardisson, C. \& Suárez, J. E. (1986). Characteristics of the developmental cycle of actinophage $\phi \mathrm{C} 31$. J Gen Microbiol 132, 1695-1701.

Ryter, A. \& Kellenberger, E. (1958). Étude au microscope electronique de plasmas contenant de l'acide désoxyribonucleique. Z Naturforsch 13, 597-605.

Tormo, A., Ayala, J. A., de Pedro, M. A., Aldea, M. \& Vicente, M.
(1986). Interaction of FtsA and $\mathrm{PBP} 3$ proteins in the Escherichia coli septum. J Bacteriol 166, 985-992.

Wang, L., Khattar, M. K., Donachie, W. D. \& Lutkenhaus, J. (1998). FtsI and FtsW are localized to the septum in Escherichia coli. J Bacteriol 180, 2810-2816.

Wong, W., Young, F. E. \& Chatterjee, A. N. (1974). Regulation of bacterial cell walls: turnover of cell wall in Staphylococcus aureus. J Bacteriol 120, 837-843.

Zajdel, J. K., Ceglowski, P. \& Dobrzanski, W. (1985). Mechanism of action of lactostrepcin 5, a bacteriocin produced by Streptococcus cremoris 202. Appl Environ Microbiol 49, 969-974.

Received 29 July 1999; revised 24 December 1999; accepted 10 January 2000. 